\title{
96. Die chronische Stase des Duodenums und ihre chirurgische Behandlung
}

K. Asp*, M. MurtomaA und G. Elfving-Helsinki/Finnland

\section{Chronic Duodenal Stasis}

Summary. The authors treated 17 cases of duodenal stasis. The most important aetiological factor was "arteria mesenterica superior syndrome". Other aetiological factors were intraluminal diverticula, diaphragms and strictures of the duodenum as well as external compression. The diagnosis is based on X-rays of the stomach, hypotonic duodenography and angiography. Duodeno-jejunostomy is recommended as the basic operative procedure.

Zusammenfassung. Die Verfasser haben 17 Fälle von Duodenalstase behandelt. Die wichtigste Ätiologie war Arteria mesenterica superior-Syndrom. Als übrige ätiologische Faktoren kamen intraluminale Divertikel, Diaphragmen und Strikturen des Duodenums sowie äußere Kompression vor. Die Diagnose gründet sich auf Magenröntgen, hypotone Duodenographie und Angiographie. Als Fundamentaloperation wird Duodenojejunostomie empfohlen.

\section{Vergleichende tierexperimentelle Untersuchungen über die Bildung eines Nahrungsreservoirs, seines Entleerungstyps und seiner Auswirkung auf die Fettresorption}

C. P. Schrader*, L. Koslowski, U. Feine und P. Konold-Tübingen

Comparative Animal-Experimental Investigations on the Formation of a Food Reservoir, Its Evacuation and Its Effect on Fat Resorption

Summary. In an animal experiment a substitute stomach was formed in 50 pigs by anisoperistaltically inserting a segment of small intestine distally to an isoperistaltic loop of small intestine interposed between oesophagus and duodenum. In several experiments the total length of the interposed loop of small intestine and the optimal proportion of the anisoperistaltic to the isoperistaltic segment were determined. A total length of $25 \mathrm{~cm}$ loop of intestine with counterinsertion of a $10 \mathrm{~cm}$ long anisoperistaltic segment produced an optimum of dilation of the food reservoir with evacuation of food in portions. Comparative tests with the types of anastomosis most commonly performed in surgical practice showed a longer stay of the food in the food reservoir, better mixing, better portioning of the food passed on to the intestine, slowing down of the passage through the intestine and better fat resorption.

Zusammenfassung. Im Tierversuch wurde an 50 Schweinen ein Ersatzmagen dadurch gebildet, daß distal einer orthograd zwischen Oesophagus und Duodenum interponierten isoperistaltischen Dünndarmschlinge ein Dünndarmsegment aniso- 